his Medical Education in Europe (1912). $\mathrm{He}$ also discusses in this chapter indirect influence of German medicine through immigrant German doctors who taught those Americans who did not go abroad to German universities. While this kind of influence is admittedly difficult to measure, Bonner presents an interesting case.

"German Universities and the Basic Medical Sciences in America" is the most important section for medical education. If the German impact upon such specialities as opthalmology, laryngology, and gynecology was profound, "the mold of the basic medical sciences in nineteenth- and twentieth-century America was cast in Germany" (p. 108). In contrast to the older men who were interested in the clinical part of medical science, the younger men, generally just out of medical school, were intrigued by the basic medical sciences, and this training was found not in Berlin and Vienna but in some of the smaller German universities, such as Leipzig, Strassburg, or Breslau. While numerically this group was not large, they exerted an impact upon American medicine out of all proportion to their numbers, for included were such men as Welch, Mall, Minot, and Chittenden. Bonner's method here is to take up various subjects such as "Pathology and Bacteriology," and trace the German influence through specific Americans who became American masters in these fields.

The last major section notes the turning of the tide: "German Doctors in America before 1914," when the visits to this country by German medical men resulted in increased respect for American medicine. Bonner takes issue with those who have dated the development of American medicine after the issuance of Flexner's famous Carnegie report in 1910. He presents rather convincing evidence that the tide had begun to turn much nearer the beginning of the twentieth century. Not that he labors the point nor loses scholarly caution in hedging his remarks, but he does point out that, from a widespread conviction that American medicine was inferior, the German doctors by 1910 were turning to praise and appreciation.

The outbreak of World War I brought to an end this almost unparalleled chapter in the transmission of scientific culture. American medicine had taken the German models, adapted them to their own situation, and had begun to forge ahead of their own teachers. Prewar Germany had been the mecca not only for American doctors but for those from England, France, and Russia as well, demonstrating the international character of science. After World War I the capital of the medical and surgical world moved across the Atlantic.

Professor Bonner has provided an interesting and informative record of the international influence of scholarship in medicine. His book is more important for the general reader than the title indicates. One can only hope that other intellectual historians will do as well for other disciplines.-Edward G. Holley, University of Houston.

\section{Special Libraries}

Medizinische Bibliotheken in der Deutschen Democratischen Republik. . . . Berlin: Deutscher Democratische Republik, Mininsterium fur Gesundheits-wesen, Abteiling Wissenschaft, 1963. 63p. and 2 plates.

This is a first attempt, made under the editorship of Edith Krauss, head of the library of the Deutsche Akademie für Arztliche Fortbildung in Berlin, to present an overview of the medical libraries in East Germany. All the medical libraries of the area are listed, plus the medical sections of large general libraries, as for example the Deutsche Staatsbibliothek in Berlin, and of university libraries. To be included, a library must have had: (1) at least five hundred volumes; (2) subscriptions to at least ten journals; (3) an alphabetical or classified catalog; or (4) a full time employee.

The entries are arranged first by place, in alphabetic order, and then by the principal words in its title. In the cities where there are many libraries, such as Berlin or Leipzig, the list is further divided by whether they are open to the public, or are in institutes and clinics, or in hospitals. The usual information is given for each place: name, telephone number, whether it circulates materials, hours of opening, holdings in books and journals, subject fields collected, catalogs, publications, number of seats in the reading room, photographic equipment, rules for readers, and the year of foundation. A subject index to the numbered en- 
tries is provided, as well as a folding map locating the libraries enumerated.

What strikes the browser in this valuable compilation is the small size of most of the collections. Obviously the traditional German system of having numerous small institute and departmental libraries still prevails today.-Estelle Brodman, Washington University School of Medicine.

\section{Directory of Special Libraries and Informa-} tion Centers. Edited by Anthony T. Kruzas. Detroit: Gale Research Company, 1963. 767 p. $\$ 25.00$.

The current emphasis on research and the information explosion which necessitates specialization in almost every field make a knowledge of the location of specialized materials imperative. This volume is an important contribution to this knowledge. Special libraries and information centers as defined in the introduction are collections that exist to meet the needs of a specialized clientele by providing them with the latest accurate information regardless of where and in what form it may be available. Hence the collection in a special library or information center may consist of published or unpublished material of many types, may contain no books, and is often organized and administered by unconventional methods. This directory lists and gives information about more than ten thousand such collections located in colleges and universities, public libraries, business and industrial firms, government agencies and departments, nonprofit institutions, associations, and societies, autonomous libraries, and private collections.

The format of the directory is similar to that of the Encyclopedia of Associations issued by the same publisher. Entries in a double column to the page are alphabetical by name of the organization or library with separate alphabetical lists for the United States and Canada. All libraries associated with an organization are grouped under the official name of the organization and the major governmental libraries under the United States and Canada, with cross references for libraries with more than one sponsor. Information given for each library includes the following items, whenever obtainable: name of the sponsoring or support- ing organization; name of the library or information center; designation of the library's major subject category; address and telephone number; name of the person directly in charge; founding date; size of professional and nonprofessional staff; important subjects represented in the collection; special or unique collections; size of holdings; services available to the public; publications regularly issued by the library; names and titles of professional and supervisory staff members.

Nine appendixes assist further in the location of specialized information by listing the U.S. Information Agency libraries, the United States regional libraries for the blind, the United States government depository libraries, the U.S. Army Map Service depository libraries, the libraries with United States patent files, the United States regional technical report centers, the U.S. Atomic Energy Commission depository libraries, libraries in the United States and Canada receiving United Nations material, and libraries of the United Nations specialized agencies.

A subject index, with reference by page number and item location on the page, refers to each collection which contains material on the subject listed. Although the system for indicating location of the libraries on any given page is cumbersome and time consuming, it is possible through the index to locate the collections dealing not only with the major fields of interest but also with many unusual topics. For instance, we find that there are in the American Christmas Crib Society library five hundred books, three hundred manuscripts, five thousand magazines, five thousand letters and clippings, six hundred and fifty slides, and ten thousand photographs dealing with Christmas alone; that the library of the United Federation of Doll Clubs contains nothing but material on the history, materials, trademarks, etc. of dolls; that there are, among other things, five hundred thousand abandoned patent applications in the scientific library of the U. S. Patent Office; that the American Museum of Comedy library and research center contains one million jokes and cartoons as well as books; and that the library of Rescue, Inc. is made up of 1105 books and 380 bound periodicals dealing with suicide, murder, and mental illness.

For librarians one of the most useful fea- 